* Corresponding author E-mail address: attila.herditzky@gmail.com

Article information

Article history: AMS-Volume15-No.3-00116-11 Received 21 May 2011

Accepted 18 June 201

\section{Verification of the Effect of Tempera- ture and Duration of Stamina for Heat Treatment of Zinc Coating on the Formability of Procedural AHSS Steels}

\author{
Slavomír Pavelčák, Emil Spišák, Attila Herditzky* , Peter Svantner
}

a Department of Technologies and Materials, Faculty of Mechanical Engineering, Mäšiarska 74, 04001 Košice, Slovak Republic

\section{BIOGRAPHICAL NOTES}

Slavomír Pavelčák, Ing. works as a clerk at the District Office in Kosice. He is postgraduate student at the Faculty of mechanical engineering, at the department of Technology and Materials. He has started his university studies in October 2007, with expected finish in May 2012. The advisor of his study and research is Mr. prof. Ing. Emil Spišák, Csc. He's working on dissertation thesis: Identifying correlation between stampability characteristics and material properties steel sheets.

Emil Spišák, prof. CSc. (born in 1955) is professor of Department of Technologies and Materials, Faculty of Mechanical Engineering, Technical University of Košice. He is head of the Department of Technologies and Materials and Vice-Rector for Development and Construction of the University. He served as Vice-Dean for 4 years and Vice-Rector for 8 years. He works in the area of evaluating of material properties, material failures, analysis and quantification of production factors influence in production of thin steel sheet stamping parts, modelling and simulation of technological processes, mainly forming processes. He is national secretary and a member of International DeepDrawing Research Group. He is author of 5 monographs and more than 200 publications in journals and conference proceedings at Slovakia and abroad. His published works were cited 115 times. He has been worked on 60 grant projects, research tasks and 47 projects solved for industry.

Attila Herditzky, Ing. PhD. is a teacher at a Jozef Szakkay - secondary technical school. He received M.Sc. degree in the field of Mechanical Engineering Technologies and Materials, at Faculty of Mechanical Engineering at Technical University of Košice in 2007. In 2010 he defended his dissertation at the same university. His current field of interest is focused on the compressibility of multiphase steel sheets.

Peter Švantner, Ing., is a PhD. student of the Department of Technologies and Materials at Faculty of Mechanival Engineering at Technical University of Košice. He received B.Sc and M.Sc. degree in field of Computer aided mechanical engineering at the same university in 2008 and 2010. His current field of interest is focused on the area of sheet metals for automotive industry and sheet metals with high strength applications.

\section{KEYWORDS}

Multiphase Steel, Zinc Coating, Galvannealing, Cupping Test, the Marginal Coefficient of Drag

\section{ABSTRACT}

Subject of presented contribution is process formability parameters evaluation of both 
side coated TRIP and HSLA steels in basic state and after its annealing in order to Fe-Zn coating creation. The samples were annealed at 450, 500 and $550^{\circ} \mathrm{C}$ for 10 and 60 seconds in argon shielding gas. Obtained values are compared with each other in order to determine whether the influence of temperature and duration after annealing changed the original class inclusion on a scale to measure the quality of steel sheets for deep drawing according to the value of limit drawing ratio. Limit drawing ratio was used as a process formability criterion and were reached by modified Swift cupping test. HSLA steel H220PD and TRIP steel RAK40/70 were used as experimental materials.

\section{Introduction}

The main reasons for the use of steel in the construction of vehicle bodies are their strength properties, processability, relatively low cost and recyclability. Requirements for sheet metal are often contradictory. From a structural point of view there is effort to reduce sheet thickness while increasing their strength and dynamic resistance. To increase the resistance to indentation and at the same time ensuring a high absorption of energy in a vehicle accident when applying a thin sheet. From a technological point of view of manufacturing moldings body parts to enhance the requirements for their high plasticity and homogeneity properties. Of course, that sheet should also be resistant against aggressive external environment, which provides not only its structure (eg Cr content), but especially its coating (hot dip galvanizing, electrolytic zinc). Specific technology requirements and designing the material properties of individual components, therefore lead to the development of specialized products for niche applications. The picture No.1 shows the skeleton of the car body with representation of the modern conceived steel sheets, which are usually coated on both sides.

Another possible type of zinc coatings are Fe-Zn coatings, which exhibit better weld ability, corrosion resistance and material savings in comparison with pure zinc coatings. These coatings are obtained by annealing Zn coatings. Annealing after galvanizing is the process by which the transformation occurs in pure $Z n$ coating on the intermetallic compound Fe-Zn through diffusion between $\mathrm{Zn}$ and steel foundation, which is usually performed in the temperatures between $440^{\circ} \mathrm{C}$ and $550^{\circ} \mathrm{C}$.
Because shown temperatures are in the recovery of material forming temperature (warm forming), there is influence of the substrate in the development of Fe-Zn coating. [2]

The article presents to verification of the effect of temperature and duration for heat treatment of zinc coatings on marginal factor in the cup drawing test. Test principle is illustrated in Fig. 2.

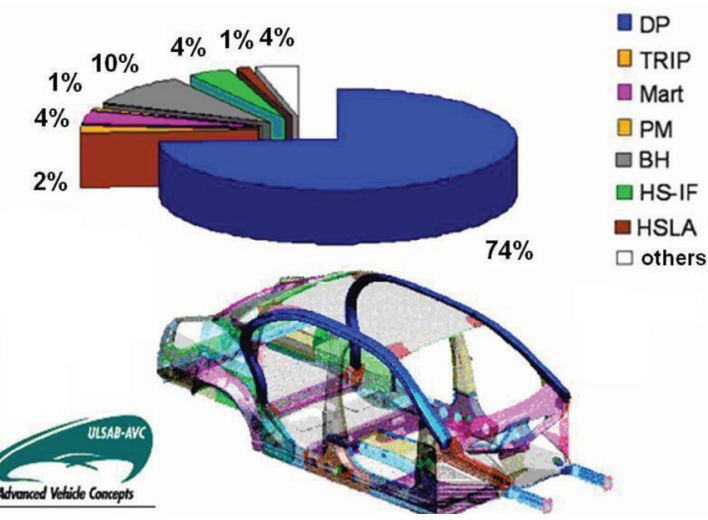

Fig. 1: The various types of steel used in the manufacture of body skeleton. [1]

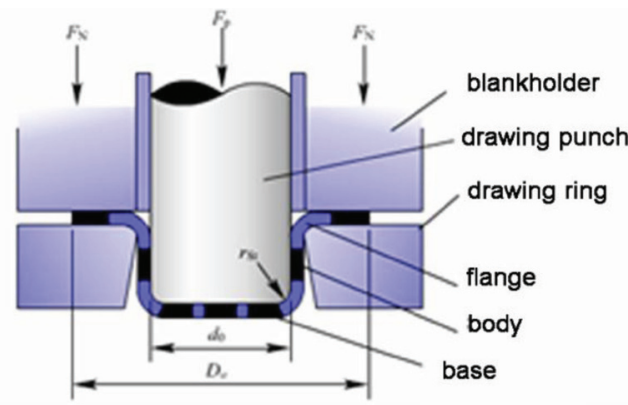

Fig. 2: Scheme of the cup test.

The circular test specimens with a diameter of $D_{0}$ are gradually increased drawn cylindrical extracts and the maximum diameter $\mathrm{D}_{\text {omax }}$ is sought, which can be taken out intact cup. In deep drawing, there is a marginal relationship between the diameter of circular blanks and depth of yield, which is proportional to its diameter " $\mathrm{d}$ ". Marginal drag coefficient, denoted as $m$ is determined by cup test of (1).

$m=\frac{d_{0}}{D_{0 \max }}$

Where $D_{\text {omax }}$ is the maximum diameter blanks, in which there was no breach of extract, $d_{0}$ is the average yield. [3] 


\section{Perfomed Experiments and their Results}

Material that was used in experiments:

- Alloy Steel H220PD, $a_{0}=0.80 \mathrm{~mm}^{-}{ }^{\prime} \mathrm{M}^{\prime}$

- Steel with induced transformated plasticity and TRIP RAK40/70 $a_{0}=0.75 \mathrm{~mm}$ with a sign - " $T$ "

- Steel plates rated M, T are mutually electrolytic zinc, where the amount of zinc is $100 \mathrm{~g} / \mathrm{m}^{2}$ (Z100MBO). Chemical composition of samples is given in Table 1.

Table 1: Chemical composition of steels [\%].

\begin{tabular}{|c|c|c|}
\hline & $\mathbf{M}$ & $\mathbf{T}$ \\
\hline $\mathbf{C}$ & 0,004 & 0,204 \\
\hline $\mathbf{M n}$ & 0,415 & 1,683 \\
\hline $\mathbf{P}$ & 0,042 & 0,018 \\
\hline $\mathbf{T i}$ & 0,004 & 0,003 \\
\hline $\mathbf{S i}$ & 0,037 & 0,009 \\
\hline $\mathbf{A l}$ & 0,1 & 0,2 \\
\hline $\mathbf{C r}$ & 0,035 & 1,73 \\
\hline $\mathbf{C u}$ & 0,031 & 0,055 \\
\hline $\mathbf{N i}$ & 0,011 & 0,028 \\
\hline $\mathbf{N b}$ & 0,017 & 0,018 \\
\hline $\mathbf{M o}$ & 0,026 & 0,004 \\
\hline $\mathbf{Z r}$ & 0,005 & 0,008 \\
\hline
\end{tabular}

The conversion of $\mathrm{Zn}$ layer annealing was performed in laboratory conditions according to methodology developed and documented in $[5,6]$. For these purposes, was used kantalová flow furnace REH-B-10-60 Ø90 mm with quartz retort.[4]

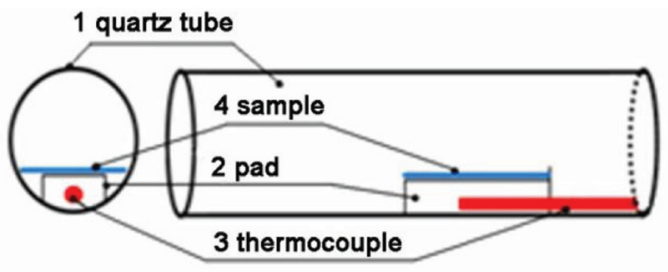

Fig. 3: Deposit the sample in the furnace kantalovej.

From appointed materials samples were taken with size $160 \times 80 \mathrm{~mm}$, which were annealed at 450, 500 and $550^{\circ} \mathrm{C}$ with exposure time 10 and $60 \mathrm{sec}-$ onds. Scheme of deposit of samples in the furnace is outlined in Fig. 3 In the furnace system was used to flow gas through the retort, thereby ensuring air that cools gas samples. When the heat treatment was performed, argon shielding gases consisting of $99.99 \%$ purity were used. Selected samples from the furnace after endurance were freely cooled in air. $[5,6]$

For purposes of the cup test there were made circular blanks with a diameter of 52, 60, 68 and $80 \times 140$ blanks from which the extracts were drawn cylindrical flat-bottomed $31 \mathrm{~mm}$ in diameter in figure drawing tools on a laser cutting machine shown in Fig. 4 with parameters:

\section{- diameter of median dte: $33.0 \mathrm{~mm}$ \\ - diameter of puncheon dbp: $31.0 \mathrm{~mm}$ \\ - pulling gap tm: $1.0 \mathrm{~mm}$ \\ - radius of puncheon $r$ tk: $4.5 \mathrm{~mm}$ \\ - radius of median rte: $6.0 \mathrm{~mm}$}

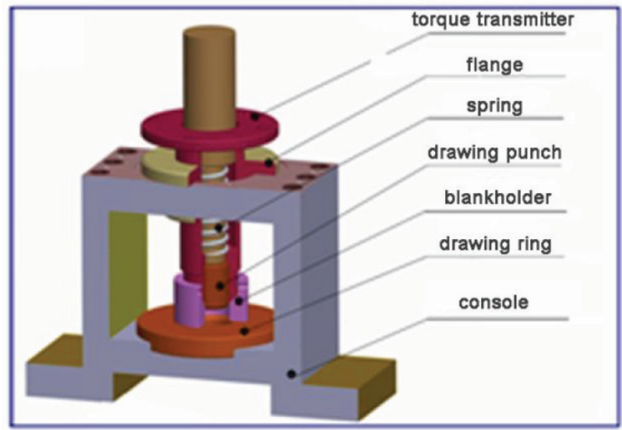

Fig. 4: The tool used for cups. test.

Measurement device that was used (Fig. 5).

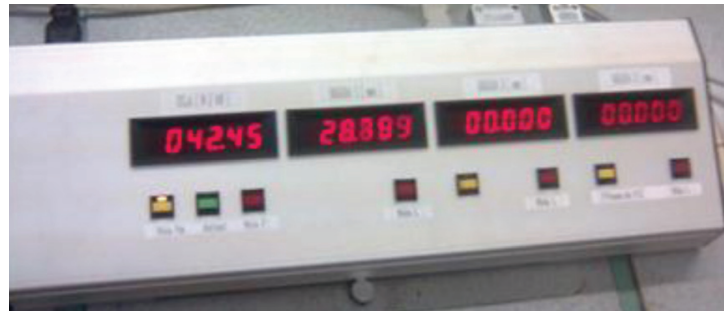

Fig. 5: Evaluative device

allows to capture the pressure of the press in real time and display measured values on a light transmitting panels, while transforming the values to the computer, where they are stored and can be further evaluated and treated. Plastic wrap as a lubricant was used in this test. Holding force on the trapezoidal threads was caused by torque wrench for microalloyed steel $\mathrm{Mk}=70 \mathrm{~nm}$ and for the TRIP steel it was Mk $=85 \mathrm{Nm}$. Right measurement was ensured by this. $[7,8]$ 
Table 2: Measured traction force in cup test for samples $M$.

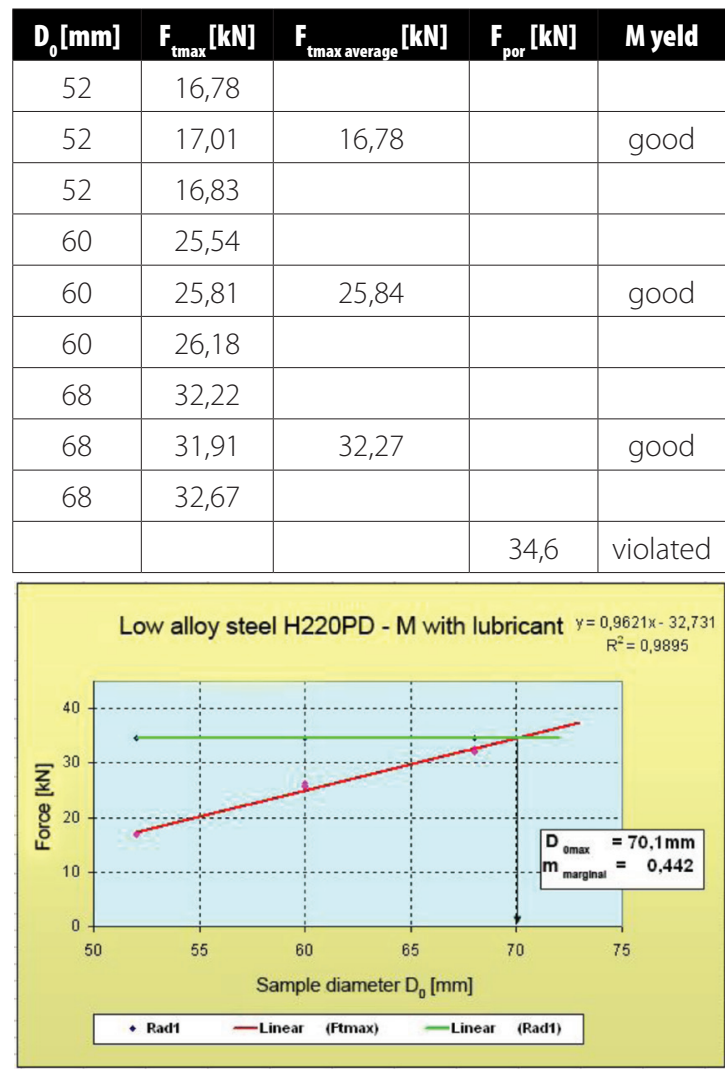

Fig. 6: Determination of cut-off diameter of blanks for the sample $M(d=31 \mathrm{~mm})$.

Table 3: Measured traction force in cup test for T samples.

\begin{tabular}{|c|c|c|c|c|}
\hline $\mathbf{D}_{\mathbf{0}}[\mathbf{m m}]$ & $\mathbf{F}_{\text {tmax }}[\mathbf{k N ]}$ & $\mathbf{F}_{\text {tmax average }}[\mathbf{k N}]$ & $\mathbf{F}_{\text {por }}[\mathbf{k N}]$ & M yeld \\
\hline 52 & 30,32 & & & \\
\hline 52 & 30,28 & 30,33 & & good \\
\hline 52 & 30,39 & & & \\
\hline 60 & 45,18 & & & \\
\hline 60 & 45,21 & 45,32 & & good \\
\hline 60 & 45,58 & & & \\
\hline 68 & 58,25 & & & \\
\hline 68 & 58,80 & 58,58 & & good \\
\hline 68 & 58,58 & & & \\
\hline & & & 34,6 & violated \\
\hline
\end{tabular}

Maximum measured traction forces for various diameters of the blanks and strength to breach the bottom of the sample labeled $M$ (Alloy steel) in not ignited state are shown in Tab. 2. Marginal diameter blanks defined mathematically (Fig. 6) is $D_{0 \max }$
$=70.1 \mathrm{~mm}$. Marginal factor in drawing 1.draw of considered metal $M$ has a value of $m=0.442$ on a scale quality is the EDDQ-S class.

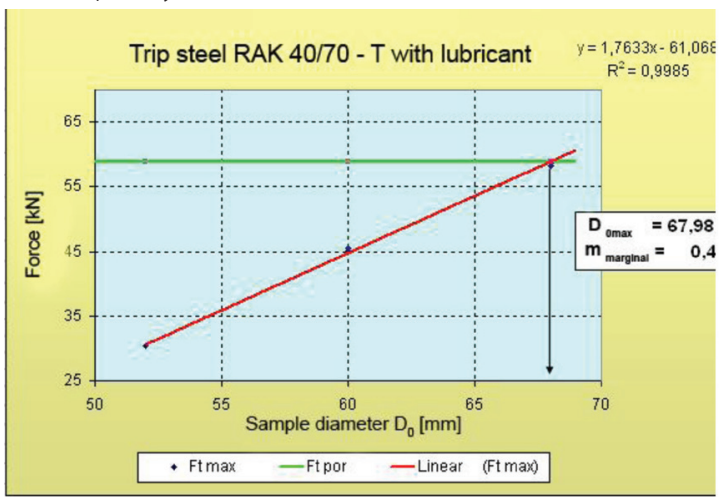

Fig. 7: Determination of the average blanks for the $T$ sample $(d=$ $31 \mathrm{~mm})$.

Maximum measured traction forces for various diameters of the blanks and strength to breach the material bearing the T (TRIP steel RAK40/70) in not ignited state are shown in Tab. No. 3. Marginal diameter blanks defined mathematically (Fig. 7) is D0max $=67.98 \mathrm{~mm}$. Marginal factor in drawing of 1.draw of examination of $T$ sheet has a value of $m$ $=0.456$ based quality assessment scale is category EDDQ

Quality scale sheet by breaking drag coefficient:
- $m m \leq 0,45$
$E D D Q-S$
mm $m=0,45 \div 0,48$
$E D D Q$
a $m m=0,48 \div 0,50$
$D D Q$
a $m=0,50 \div 0,55$
$D Q$ [9]

In Tab. 4 there are recorded measured peak traction forces for various diameters of the blanks and strength to breach the bottom of the sample labeled M (Alloy steel) in the annealed condition. As seen from the dependence of tensile force from the diameters of the blanks to a temperature no significant change in mechanical properties of the basic material. The effect of heat treatment had little effect on the properties sheet. Compared to the baseline condition at $450^{\circ} \mathrm{C}$, the force required to pull the cup rose is almost $1 \mathrm{kN}$.

Subsequently, the samples with higher temperature $500^{\circ} \mathrm{C}$ and $550^{\circ} \mathrm{C}$ the force needed to pull the cup around the value reached in pulled samples of the ground state again decreased. Tab. 5 shows the diameter limit values and limit drag coefficients, depending on heat treatment of samples on Fig. 8 is a graphical representation of changes in mar 
ginal drag coefficients depending on temperature and endurance which decreased slightly only at a temperature of $5000^{\circ} \mathrm{C}$ and last 10 with a slightly increased.

Table 4: Maximum traction force for individual samples M (H22OPD steel in annealed condition of annealing time 10s, 60s) [7].

\begin{tabular}{|c|c|c|c|}
\hline \multicolumn{4}{|c|}{ Temperature $450^{\circ} \mathrm{C} /$ time $10 \mathrm{~s}$} \\
\hline \multirow{3}{*}{$\begin{array}{c}\text { Measurement } \\
\text { number }\end{array}$} & \multicolumn{3}{|c|}{ Sample diameter $\emptyset[\mathrm{mm}]$} \\
\hline & 68,00 & 60,00 & 52,00 \\
\hline & $\mathrm{F}_{\mathrm{t}}[\mathrm{kN}]$ & $\mathrm{F}_{\mathrm{t}}[\mathrm{kN}]$ & $\mathrm{F}_{\mathrm{t}}[\mathrm{kN}]$ \\
\hline 1 & 32,85 & 26,25 & 17,16 \\
\hline 2 & 33,16 & 26,28 & 17,61 \\
\hline 3 & & 26,17 & 17,61 \\
\hline Average & 33,01 & 26,23 & 17,46 \\
\hline F por. & & & 35,93 \\
\hline \multicolumn{4}{|c|}{ Temperature $500{ }^{\circ} \mathrm{C} /$ time $10 \mathrm{~s}$} \\
\hline \multirow{3}{*}{$\begin{array}{l}\text { Measurement } \\
\text { number }\end{array}$} & \multicolumn{3}{|c|}{ Sample diameter Ø[mm } \\
\hline & 68,00 & 60,00 & 52,00 \\
\hline & $F_{t}[\mathrm{kN}]$ & $\mathrm{F}_{\mathrm{t}}[\mathrm{kN}]$ & $\mathrm{F}_{\mathrm{t}}[\mathrm{kN}]$ \\
\hline 1 & 33,21 & 26,34 & 17,32 \\
\hline 2 & 33,14 & 26,08 & 17,12 \\
\hline 3 & 33,33 & 26,11 & 17,60 \\
\hline Average & 33,23 & 26,18 & 17,35 \\
\hline F por. & & & 35,4 \\
\hline \multicolumn{4}{|c|}{ Temperature $550^{\circ} \mathrm{C} /$ time $10 \mathrm{~s}$} \\
\hline \multirow{3}{*}{$\begin{array}{c}\text { Measurement } \\
\text { number }\end{array}$} & \multicolumn{3}{|c|}{ Sample diameter $\emptyset[\mathrm{mm}]$} \\
\hline & 68,00 & 60,00 & 52,00 \\
\hline & $\mathrm{F}_{\mathrm{t}}[\mathrm{kN}]$ & $\mathrm{F}_{\mathrm{t}[\mathrm{kN}]}$ & $\mathrm{F}_{\mathrm{t}}[\mathrm{kN}]$ \\
\hline 1 & 32,90 & 26,23 & 17,26 \\
\hline 2 & 32,94 & 26,13 & 17,03 \\
\hline \multicolumn{4}{|l|}{3} \\
\hline Average & 32,92 & 26,18 & 17,15 \\
\hline F por. & & & 35,32 \\
\hline
\end{tabular}

\begin{tabular}{|c|c|c|c|}
\hline \multicolumn{4}{|c|}{ Temperature $450^{\circ} \mathrm{C} /$ time $60 \mathrm{~s}$} \\
\hline \multirow{3}{*}{$\begin{array}{c}\text { Measurement } \\
\text { number }\end{array}$} & \multicolumn{3}{|c|}{$\begin{array}{c}\text { Sample diameter } \\
\varnothing[\mathrm{mm}]\end{array}$} \\
\hline & 68,00 & 60,00 & 52,00 \\
\hline & $\mathrm{F}_{\mathrm{t}}[\mathrm{kN}]$ & $\mathrm{F}_{\mathrm{t}}[\mathrm{kN}]$ & $F_{[}[k N]$ \\
\hline 1 & 32,94 & 26,34 & 17,11 \\
\hline 2 & 2,60 & 26,29 & 17,47 \\
\hline 3 & 33,34 & & 17,42 \\
\hline Average & 32,96 & 26,32 & 17,33 \\
\hline F por. & & & 35,91 \\
\hline \multicolumn{4}{|c|}{ Temperature $500{ }^{\circ} \mathrm{C} /$ time $60 \mathrm{~s}$} \\
\hline \multirow{3}{*}{$\begin{array}{c}\text { Measurement } \\
\text { number }\end{array}$} & \multicolumn{3}{|c|}{$\begin{array}{c}\text { Sample diameter } \\
\varnothing[\mathrm{mm}]\end{array}$} \\
\hline & 68,00 & 60,00 & 52,00 \\
\hline & $\mathrm{F}_{\mathrm{t}}[\mathrm{kN}]$ & $\mathrm{F}_{\mathrm{t}}[\mathrm{kN}]$ & $\mathrm{F}_{\mathrm{t}[\mathrm{kN}]}$ \\
\hline 1 & 32,20 & 26,35 & 17,29 \\
\hline 2 & 32,97 & 26,48 & 17,41 \\
\hline & 33,13 & 26,43 & 17,36 \\
\hline Average & 32,77 & 26,42 & 17,35 \\
\hline F por. & & & 35,65 \\
\hline \multicolumn{4}{|c|}{$\begin{array}{c}\text { Temperature } 550^{\circ} \\
\mathrm{C} / \text { time } 60 \mathrm{~s}\end{array}$} \\
\hline \multirow{3}{*}{$\begin{array}{l}\text { Measurement } \\
\text { number }\end{array}$} & \multicolumn{3}{|c|}{$\begin{array}{r}\text { Sample diam } \\
\varnothing[\mathrm{mm}]\end{array}$} \\
\hline & 68,00 & 60,00 & 52,00 \\
\hline & $\mathrm{F}_{\mathrm{t}}[\mathrm{kN}]$ & $\mathrm{F}_{\mathrm{t}}[\mathrm{kN}]$ & $F_{[}[\mathrm{kN}]$ \\
\hline 1 & 31,68 & 25,85 & 16,87 \\
\hline 2 & 32,14 & 25,99 & 16,44 \\
\hline 3 & & 25,68 & 17,47 \\
\hline Average & 31,91 & 25,84 & 16,93 \\
\hline F por. & & & 34,87 \\
\hline
\end{tabular}

Table 5: Table of limit values of diameters and limit drag coefficients for microalloyed steel depending on the condition of heat treatment.

\begin{tabular}{|c|c|c|c|c|c|c|c|}
\hline & $\begin{array}{l}\text { base } \\
\text { state }\end{array}$ & $450 \mathrm{Cr} 10 \mathrm{~s}$ & $4500 \mathrm{C} / 100 \mathrm{~s}$ & $500 \mathrm{c} / 10 \mathrm{~s}$ & 50001605 & $550^{\circ} \mathrm{C} / 10 \mathrm{~s}$ & $550^{\circ} \mathrm{C} / 60 \mathrm{~s}$ \\
\hline $\mathrm{m}[-]$ & 0.42 & 0.439 & 0,439 & 0,44 & 0.439 & 0.44 & 0.499 \\
\hline do $[\mathrm{mm}]$ & 70.1 & 70.66 & 70.62 & 69.89 & 70.55 & 70.05 & 70.68 \\
\hline
\end{tabular}

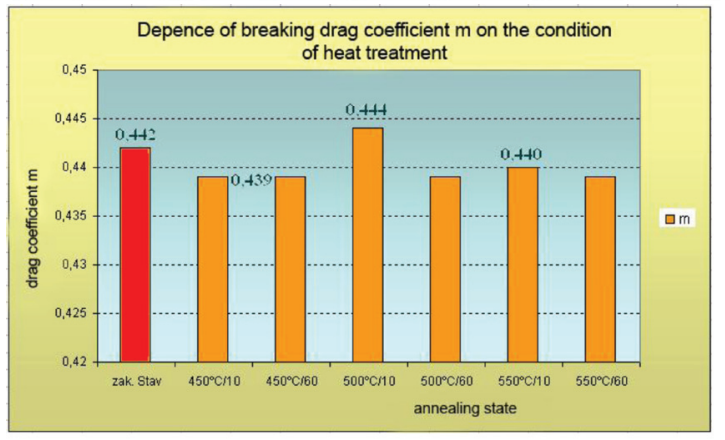

Fig. 8: Dependence of breaking drag coefficient m on the condition of heat treatment for microalloyed steel.

In Tab. 6 there are recorded measured peak traction forces for various diameters of the blanks and strength to breach the bottom of the sample labeled T (TRIP steel) in the annealed condition. As seen from the dependence of tensile force from the diameters of the blanks to a temperature caused a slight decrease in the force needed to pull in an average yield of $4 \mathrm{kN}$ and also decreased the force required to break the bottom.

In Tab. 7 there are the limit values of diameters and limit drag coefficients, depending on heat treatment of samples.

Table 6: The maximum traction force for individual samples $T$ (TRIP steel in the annealed state annealing time 10s, 60s) [7].

\begin{tabular}{|c|c|c|c|}
\hline \multicolumn{4}{|c|}{ Temperature $450^{\circ} \mathrm{C} /$ time $10 \mathrm{~s}$} \\
\hline \multirow{3}{*}{$\begin{array}{c}\text { Measurement } \\
\text { number }\end{array}$} & \multicolumn{3}{|c|}{ Sample diameter Ø[mm] } \\
\hline & 68,00 & 60,00 & 52,00 \\
\hline & $\mathrm{F}_{\mathrm{t}}[\mathrm{kN}]$ & $\mathrm{F}_{\mathrm{t}}[\mathrm{kN}]$ & $\mathrm{F}_{\mathrm{t}}[\mathrm{kN}]$ \\
\hline 1 & 52,91 & 41,95 & 28,28 \\
\hline 2 & 53,34 & 42,26 & 28,74 \\
\hline 3 & 52,63 & & 29,00 \\
\hline Average & 52,96 & 42,11 & 28,67 \\
\hline F por. & & & 53,34 \\
\hline \multicolumn{4}{|c|}{ Temperature $500^{\circ} \mathrm{C}$ time $10 \mathrm{~s}$} \\
\hline \multirow{3}{*}{$\begin{array}{l}\text { Measurement } \\
\text { number }\end{array}$} & \multicolumn{3}{|c|}{ Sample diameter $Ø[\mathrm{~mm}]$} \\
\hline & 68,00 & 60,00 & 52,00 \\
\hline & $\mathrm{F}_{\mathrm{t}}[\mathrm{kN}]$ & $\mathrm{F}_{\mathrm{t}}[\mathrm{kN}]$ & $\mathrm{F}_{\mathrm{t}}[\mathrm{kN}]$ \\
\hline 1 & 55,64 & 43,67 & 28,50 \\
\hline 2 & 55,56 & 43,43 & 29,20 \\
\hline 3 & 55,67 & 43,73 & 28,97 \\
\hline Average & 55,62 & 43,61 & 28,89 \\
\hline F por. & & & 55,67 \\
\hline \multicolumn{4}{|c|}{ Temperature $550^{\circ} \mathrm{C} /$ time $10 \mathrm{~s}$} \\
\hline \multirow{3}{*}{$\begin{array}{l}\text { Measurement } \\
\text { number }\end{array}$} & \multicolumn{3}{|c|}{ Sample diameter $Ø[\mathrm{~mm}]$} \\
\hline & 68,00 & 60,00 & 52,00 \\
\hline & $\mathrm{F}_{\mathrm{t}}[\mathrm{kN}]$ & $\mathrm{F}_{\mathrm{t}}[\mathrm{kN}]$ & $\mathrm{F}_{\mathrm{t}}[\mathrm{kN}]$ \\
\hline 1 & 54,42 & 44,19 & 29,79 \\
\hline 2 & 52,00 & 43,35 & 29,79 \\
\hline 3 & 53,77 & & \\
\hline Average & 53,40 & 43,77 & 29,79 \\
\hline F por. & & & 54,42 \\
\hline
\end{tabular}

\begin{tabular}{|c|c|c|c|}
\hline \multicolumn{4}{|c|}{ Temperature $450^{\circ} \mathrm{C}$ time $60 \mathrm{~s}$} \\
\hline \multirow{3}{*}{$\begin{array}{l}\text { Measurement } \\
\text { number }\end{array}$} & \multicolumn{3}{|c|}{$\begin{array}{c}\text { Sample diameter } \\
\varnothing[\mathrm{mm}]\end{array}$} \\
\hline & 68,00 & 60,00 & 52, \\
\hline & $\mathrm{F}_{\mathrm{t}}[\mathrm{kN}]$ & & \\
\hline 1 & 4,11 & 42,19 & \\
\hline 2 & 95 & 2,23 & \\
\hline 3 & 4,27 & & 28, \\
\hline Averas & 54,11 & & 28, \\
\hline F por. & & & 54,2 \\
\hline \multicolumn{4}{|c|}{ Temperature $500^{\circ} \mathrm{C}$ time $60 \mathrm{~s}$} \\
\hline \multirow{3}{*}{$\begin{array}{c}\text { Measurement } \\
\text { number }\end{array}$} & \multicolumn{3}{|c|}{$\begin{array}{c}\text { Sample diameter } \\
\varnothing[\mathrm{mm}]\end{array}$} \\
\hline & 68,00 & 60,00 & 52,0 \\
\hline & $\mathrm{F}_{\mathrm{t}}[\mathrm{kN}]$ & & $\mathrm{F}_{\mathrm{t}}[\mathrm{k}$ \\
\hline & 5,43 & & 29. \\
\hline 2 & 55,92 & 43,97 & 27,5 \\
\hline 3 & 55,57 & 44, & 29, \\
\hline Avera & 55,64 & 44,05 & 28 \\
\hline F por. & & & 55, \\
\hline \multicolumn{4}{|c|}{ Temperature $550^{\circ} \mathrm{C}$ time $60 \mathrm{~s}$} \\
\hline \multirow{3}{*}{$\begin{array}{c}\text { Measurement } \\
\text { number }\end{array}$} & \multicolumn{3}{|c|}{$\begin{array}{r}\text { Sample diam } \\
\varnothing[\mathrm{mm}] \\
\end{array}$} \\
\hline & 68,00 & 60,00 & 52. \\
\hline & $\mathrm{F}_{\mathrm{t}}[\mathrm{kN}]$ & & \\
\hline 1 & 55,42 & 43, & 29 \\
\hline 2 & 54,17 & 43,30 & $28 ;$ \\
\hline 3 & & & \\
\hline Average & 54,80 & 43,33 & 29. \\
\hline F por. & & & 55, \\
\hline
\end{tabular}

Table 7: Table of limit values of diameters and limit drag coefficients for TRIP steel depending on the condition of heat treatment.

\begin{tabular}{|c|c|c|c|c|c|c|c|}
\hline & $\begin{array}{l}\text { base } \\
\text { state }\end{array}$ & $450^{\circ} \mathrm{C} / 10$ & $4500^{\circ} \mathrm{C} 100$ & $50000 / 11$ & $500^{\circ}<100$ & 1550"C/10 & $0.5500^{\circ} \mathrm{C} 100$ \\
\hline $\mathrm{n}[-]$. & 0.456 & 0.456 & 8.0 .457 & 0.45 & $\begin{array}{ll}8 & 0.45 \\
\end{array}$ & 7. 0.454 & $\begin{array}{ll}4 & 0.455\end{array}$ \\
\hline $6[\mathrm{~mm}]$ & 67.98 & 67.96 & 67.80 & 67.7 & 67.81 & 68.2 & 6 \\
\hline
\end{tabular}

In Fig. 9 there is a graphical representation of changes in marginal drag coefficients depending on temperature and endurance. Dependence of breaking drag coefficient $(\mathrm{mm})$ of annealed TRIP steel shows that with increasing annealing temperature and time increasing the marginal factor into drawing temperature of $500^{\circ} \mathrm{C}$ which is the adverse effect of annealing. At $550^{\circ} \mathrm{C}$ and endurance 
10 and 60 seconds there is a slight decrease in the ultimate drag coefficient compared to the baseline condition.

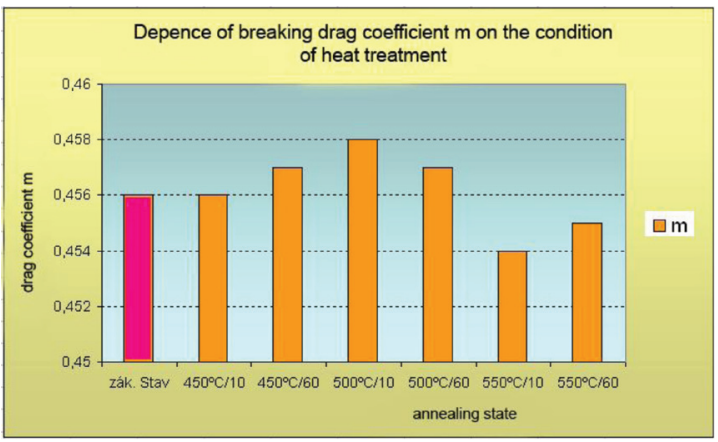

Fig. 9: Dependence of breaking drag coefficient $m$ on the condition of heat treatment for TRIP steel [9].

\section{Conclusion}

The paper presents test results of process evaluation of formability of steel sheet used in automotivemicroalloyed steel and TRIP steel H220PD RAK40/70. Assessed process sheet formability was rated by cup test, during which was rated marginal dragging factor. Drag coefficient was found in microalloyed steel $m=0.442$ and TRIP steel $m=0.456$. These types of plates used in the automotive industry can classified the level of quality EDDQ-S for microalloyed steel or EDDQ for TRIP steel. Because of temperature and duration of stamina the changes in breaking drag coefficient for both steels occur. In microalloyed steels is a drop to $500{ }^{\circ} \mathrm{C}$ at the time of stamina 10 s. In contrast, TRIP steel cut-off factor increases slightly at temperatures up to $500{ }^{\circ} \mathrm{C}$ and to $550{ }^{\circ} \mathrm{C}$ in the stamina 10 and 60 seconds drops slightly below its original value in the annealed condition. However, we can conclude on the basis of measured results that overrun of the limits didn't occur in any of the groups of material.

\section{Acknowledge}

This work was supported by Agency to support research and development on the basis of the contract nr. APVV-0629-06 [10].

\section{References}

[1] http://www.salzgitterflachsthal.de/en/News/Archiv/2500/ dual_Phase_in_feuerveryinkter_Ausfuehrun[cit:10.10.2010]

[2] HUDÁK, J. -TOMAŠ, M.: VPLYV TEPLOTY A DOBY VÝDRŽE PRI ŽÍHANÍ Zn POVLAKU NA MATERIÁLOVÚ TVÁRNITELNNOSŤ AHSS OCELÍ. In: Transfér inovácií. Košice: SjF TU, č.15 2009 str. 128-131

[3] JANKURA, D.- BREZINOVÁ, J.: Technické materiály Laboratórne cvičenia, Košice 2006 ISBN 80-8073-412-7

[4] ČAJKOVÁ, L. - DŽUPON, M. - JAKUBÉCZYOVÁ, D:: Spôsob prípravy Fe-Zn povlakov na žiarpvo pozinkovaných ocelových plechoch. Acta Měchanica Slövaca, roč. 12, č. 4-B/2008, s. 40-45, ISSN 1335-2393

[5] KOLLÁROVÁ, M.- DŽUPON,- LEŠKO, A. -PARILÁK, L'.: Formation of Oytburst Structure in Hot Dip Galvannealed Coatings on If Steels METALYRGIJA46 (2007)1,9-14p. 9-14

[6] Džupon, M. -Buríková, K.- Parilák, L'.: Methodology of Preparation of Dual Phase Ferrite-Martensitic Steel Micro-Alloyed With $\mathrm{V}-\mathrm{Nb}$ Manufacturing engineering Issue 1, year VII, 2008, pp. 44-48

[7] ŠVANTNER, P.: Experimentálny výskum lisovatelnosti plech̨ôv pre automobilový priemysel s modifikovaným poyrchom, Technická Univerzita v Košiciach, 2010.

[8] STN EN 1669:20p1 Skúsobné met/dy. Skúška anizotropie plechov a pásov (kališkovacia)

[9] SPIŠÁK, E. a kol.: Dizajn moderne koncipovanýgh ocelína základe charakteristík lisovatel'nosti. ARVV-0629-06

[10] POLLÁK, L.- HUDÁK, J.- POLLÁKOVÁ, G.- HANDŽÁK, M.:

Súdium procesov plastického pretvorenia pri hlbokom tahlaní. Grantový vedecký projekt č.1/334/94 Košice 1994-5
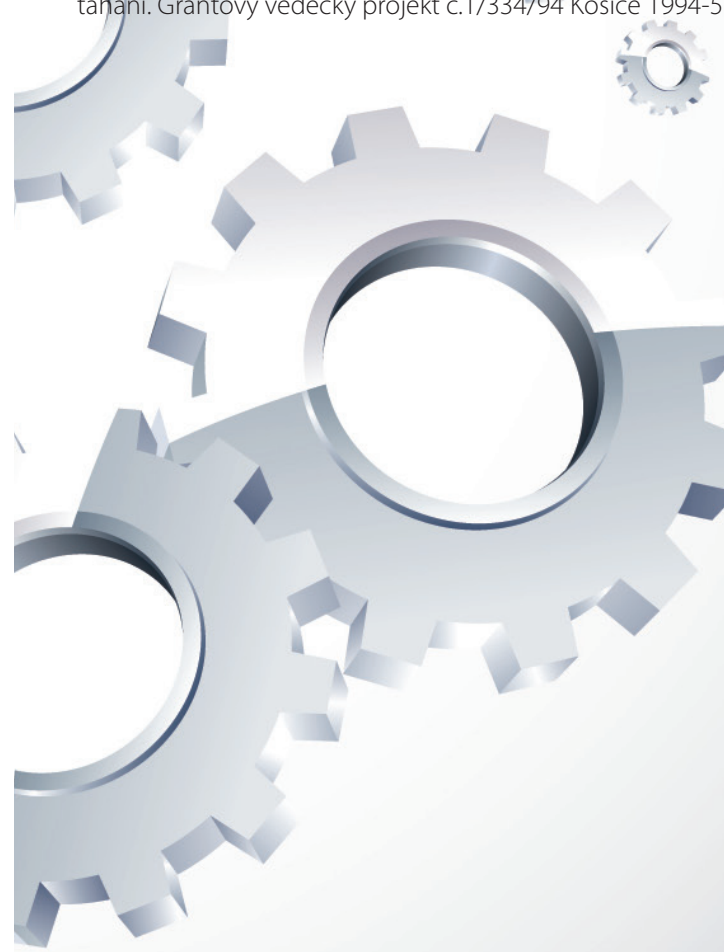